\title{
AN ANALYSIS OF ISSUES FOR THE MANAGEMENT OF POST-DISASTER HOUSING RECONSTRUCTION
}

\author{
Abdulquadri Ade BILAU a, Emlyn WITT a,* \\ ${ }^{a}$ Department of Building Production, Tallinn University of Technology, Ehitajate St. 5, EE-19086 \\ Tallinn, Estonia
}

Received 23 March 2015; accepted 31 October 2015

\begin{abstract}
There is an urgent need to improve the management of housing reconstruction programmes. Post-disaster housing reconstruction represents a significant portion of global property investment but its management has often proved to be ineffective. Although the post-disaster context makes management more challenging, it also offers exceptional opportunities to invest in and develop a more resilient built environment. On the basis of a systematic review of the existing literature, characteristics of the housing reconstruction context and successes, failures and management issues arising from historical housing reconstruction programmes were identified. These were synthesized into a conceptual framework that relates the contextual characteristics with management strategies and with the desired outcomes for housing reconstruction initiatives. This framework will enable field data collection in order to better understand the interrelationships between context, management strategies and outcomes. Ultimately, it is intended to provide practitioners with decision support tools for selecting appropriate housing reconstruction management strategies.
\end{abstract}

KEYWORDS: Built environment; Disaster resilience; Housing reconstruction; Management strategies; Reconstruction management

\section{INTRODUCTION}

One of the largest sources of global property investment has been the development of permanent housing after disasters (Tas et al. 2011). Housing typically makes up the greatest component of disaster losses with huge estimated recovery costs and, consequently, substantial funds flow towards housing reconstruction (CERA 2012; Chang-Richards et al. 2013). Lester (2003) estimated that half of post-disaster aid from the World Bank is channeled to housing reconstruction.

A disaster is a serious disruption of society that exceeds its coping capacity (EEA 2006; UN-ISDR 2007). The impacts of disasters range from physical to socio-economic effects and are felt not only by the directly affected communities but also have repercussions for surrounding communities. Impacts include deaths and injuries, damage to or outright loss of property investments and environmental losses (Otero, Marti 1995; Lindell, Prater

* Corresponding author. E-mail: emlyn.witt@ttu.ee
2003). While recorded fatalities from natural disasters appear to have been reducing in recent years (Guha-Sapir et al. 2011), there has been a marked increase in economic losses (Munich Re 2013).

The concept of housing is complex, multidimensional and dependent on the context in which it is being considered. It has variously been defined as a product (Low, Chambers 1989), a process (Agbola 1998), a human right (Nuuter et al. 2014), etc. Whatever the perspective, however, there seems to be consensus in terms of its importance to human well-being. Housing must satisfy multiple needs including physical and structural quality, location, socio-economic, cultural, psychological and neighbourhood requirements (Bourne 1981; Rapoport 2001; Aluko 2012). In the context of disasters, its location, structural integrity / state of repair and the provision of facilities and services enabling its safety and security all contribute to its exposure and ability to resist hazards (Neilson 2004). 
Post-disaster housing reconstruction offers an exceptional opportunity to invest in and develop a more robust and resilient built environment. However, many housing reconstruction initiatives, particularly in third world countries, have reproduced or even exacerbated vulnerabilities and thus failed to achieve a "bounce-forward" for the affected communities (DNS, PASA 2006; Seneviratne et al. 2010). In addition to these missed opportunities to bring about positive improvements in disaster resilience, post-disaster housing reconstruction programmes have often simply failed to deliver their stated objectives (Lyons 2009). One of the factors leading to these failures has been identified as ineffective management processes for housing reconstruction initiatives (L. Liu, J. Liu 2014).

Numerous calls for further research on disaster risk reduction and recovery in the context of the built environment have been made (for example, those by Godschalk 2003; Bosher et al. 2007; Haigh, Amaratunga 2010). Effective project organization and management of the reconstruction process have specifically been identified as important for successful housing reconstruction and for ensuring that disaster risk reduction measures are incorporated (Johnson et al. 2006; Johnson 2007; Ahmed 2011). Yet, while several different research themes have been explored (for a list of the recent research see Yi, Yang 2014), the organization and management of the housing reconstruction process for disaster risk reduction remains insufficiently investigated (Chang et al. 2010; Sadiqi et al. 2011; Ismail et al. 2014). In addition, Ahmed (2011) called for the development of global good practice guidelines for post-disaster housing reconstruction noting that, although numerous reconstruction guidelines exist, hardly any are widely endorsed.

This research is ultimately aimed at addressing the need for improved management of housing reconstruction programmes. It is intended to achieve this by developing evidence-based decision support tools for practitioners that will assist them to adopt appropriate management strategies for successful reconstruction implementation in their particular post-disaster context. However, such tools can only be developed once a thorough understanding of the interrelationships between the contextual characteristics, management strategies and outcomes of reconstruction programmes has been gained. As a first step towards achieving such understanding, a conceptual framework is needed which will provide a basis for the collection of field data. To this end, this paper analyzes the management issues identified from a systematic search of the existing literature on housing reconstruction in order to derive a proposed conceptual framework.

The research methodology is described in section 2 of this paper. Characteristics of the postdisaster context drawn from the literature are described in section 3. Successes, failures and management issues from historical reconstruction programmes are reported in section 4. Alternative approaches to managing reconstruction project delivery are outlined in section 5 and a review of typical outcome goals for housing reconstruction programmes is presented in section 6 . These findings are then synthesized into a conceptual framework that relates the specific characteristics of post-disaster contexts with management issues, elements of management strategies and outcome goals for housing reconstruction programmes (in section 7 ).

\section{RESEARCH METHODOLOGY}

A preliminary study to this research (Bilau et al. 2015) established the need to further understand the specific characteristics of the post-disaster reconstruction context and to elaborate the interrelationships between these characteristics, management approaches and housing reconstruction outcomes. Taking this forward, the present study comprises a comprehensive review of the literature to identify:

- the characteristics of the post-disaster housing reconstruction context;

- the successes and failures of past housing reconstruction initiatives;

- the management approaches to housing reconstruction;

- the intended outcome goals for housing reconstruction programmes.

The literature search followed a three-stage process. Firstly, keyword searches of databases were undertaken during January 2015. The resulting articles were then individually screened for relevance based on their titles and abstracts. Finally, the citations of all relevant articles identified were exported into an EndNote X4 library and the EndNote software was used to identify and remove duplicated references.

Six electronic databases were selected for their large collections of refereed journal articles and conference proceedings:

- Web of Science;

- EBSCO Host;

- Scopus;

- Science Direct;

- Proquest Science (Journals);

- Emerald Insight. 
Combinations of the following keywords were used in the searches: post disaster; housing; reconstruction; rebuilding; rehabilitation; project management; management framework.

After the elimination of duplicates, a total of 141 papers were identified as being relevant to this research. These formed the body of literature from which the subsequent data have been drawn.

On the basis of the contextual characteristics, successes and failures, management approaches and outcome goals identified from this body of literature, a conceptual framework reflecting how these variables interrelate was derived. The immediate purpose of this conceptual framework is to enable field data to be collected for the further development and then the validation of the framework. The data collection itself and the development and validation of the framework for selecting management strategies are beyond the scope of this paper.

\section{CHARACTERISTICS OF THE POST-DISASTER HOUSING RECONSTRUCTION CONTEXT}

The post-disaster housing reconstruction context differs markedly from that which pertains to routine construction. From the literature reviewed, numerous characteristics which define the postdisaster context were identified and these are summarized in Table 1.

\section{HOUSING RECONSTRUCTION: INSIGHTS FROM THE CASE STUDY LITERATURE}

Some of the literature identified related to case studies and experiences from specific housing reconstruction programmes. These included references to the 1999 Marmara earthquake in Turkey, the 2001 Gujarat earthquake in India, the 2003 Bam earthquake in Iran and the housing reconstruction efforts in Aceh, Indonesia and in Sri Lanka after the 2004 Indian Ocean tsunami. This case study literature was, in the first instance, reviewed in order to identify examples of successes and good practice as well as examples of failures and poor practice. It also provided further insights into some of the contextual issues (already noted in section 3 above) that affect the management of housing reconstruction initiatives.

\subsection{Successes and good practice examples}

The housing reconstruction following the 1999 Marmara earthquake in Turkey has been noted for its speed - more than 43,000 units of permanent housing in 27 different settlements were delivered in a short period of time. This was achieved through a number of measures including resettlement of communities to safer zones in conformance with a new legislative framework, a contractordriven approach to reconstruction being utilized

Table 1. Characteristics of the post-disaster reconstruction context

\begin{tabular}{|c|c|}
\hline Characteristics & Literature sources \\
\hline Acceptability of provided housing & $\begin{array}{l}\text { Barenstein (2006), UN-HABITAT (2006), Da Silva (2010), } \\
\text { Shaw, Ahmed (2010) }\end{array}$ \\
\hline $\begin{array}{l}\text { Accessibility issues - disruption of access to site and re- } \\
\text { sources }\end{array}$ & Chang et al. (2011), Tas et al. (2011) \\
\hline Bureaucratic and institutional issues in reconstruction & Sullivan (2003), Zuo et al. (2008) \\
\hline Chaotic and dynamic reconstruction environment & Davidson et al. (2007), Steinberg (2007) \\
\hline Large scale and complex reconstruction & Steinberg (2007), Felix et al. (2013) \\
\hline High exposure to health and safety hazards & Davidson et al. (2007), Kennedy et al. (2008) \\
\hline Community participation issues & Barakat (2003), Barenstein (2006), Ophiyandri et al. (2013) \\
\hline Complications to communications and coordination & McEntire (1999), Altay (2008), Shaw, Ahmed (2010) \\
\hline Extraordinary financial requirements & Lester (2003), Freeman (2004), Fengler et al. (2008) \\
\hline $\begin{array}{l}\text { High expectations on risk reduction, opportunity to "bounce } \\
\text { forward" }\end{array}$ & $\begin{array}{l}\text { El-Masri, Tipple (2002), Davidson et al. (2007), Kennedy } \\
\text { et al. (2008), Lyons (2009) }\end{array}$ \\
\hline $\begin{array}{l}\text { Requirement for quick housing reconstruction due to soci- } \\
\text { etal pressure from stakeholders }\end{array}$ & $\begin{array}{l}\text { Ahmed, McEvoy (2010), Tas et al. (2011), Iwai, Tabuchi } \\
\text { (2013) }\end{array}$ \\
\hline $\begin{array}{l}\text { Legislation issues (building code and construction guide- } \\
\text { lines, budgeting; import regulations). }\end{array}$ & $\begin{array}{l}\text { Gharaati (2007), Le Masurier et al. (2006), Fallahi (2007), } \\
\text { Zuo et al. (2008), Rotimi et al. (2009) }\end{array}$ \\
\hline Market issues - price fluctuations, inflation & Jayasuriya, McCawley (2008), Chang et al. (2011) \\
\hline $\begin{array}{l}\text { Resource challenges such as limited resource availability, } \\
\text { limitations to resource procurement }\end{array}$ & $\begin{array}{l}\text { Oxfam (2006), Steinberg (2007), Zuo et al. (2008), Chang } \\
\text { et al. (2011) }\end{array}$ \\
\hline
\end{tabular}


with contractors employed on the basis of turnkey, lump-sum contracts and the use of large numbers of subcontractors (Tas et al. 2011). The emphasis on quick housing provision was reflected in the guidelines for both design and construction which focused on simplicity, structural stability and integrity, time and cost, and also in the contracts which narrowly defined conditions for time extensions (Turkish Court of Accounts 2002 cited in Tas et al. 2011).

Aspects of good practice in planning, organization and institutional development may be drawn from the housing reconstruction programme following the 2003 Bam earthquake. A reconstruction plan that facilitated both technical and financial monitoring and control systems was put in place. Project feasibility studies were carried out. The Bam Architecture Council was established to issue orders on building designs with consideration of the socio-cultural and regional characteristics of the ailing community to aid acceptability. A number of preferred earthquake resilient housing models were offered to beneficiaries with allowance for choice in design. Building code and construction guidelines were established. Local expertise was utilized to create sources of livelihood and to promote the development of technical know-how in the community. Supervisory teams which included beneficiaries' representatives were set up to manage the reconstruction and to bring about better monitoring by both government agency representatives and beneficiaries. In this way, technical knowledge was disseminated from inspectors through the working relationships during the reconstruction and this led to reduced reconstruction times, higher production and improved quality (Gharaati 2007; GhaforyAshtiany, Hosseini 2008).

In Gujarat, the private sector was commis sioned to undertake damage assessment and engineering analysis in affected communities and a range of alternative management approaches to implementation was adopted to facilitate housing reconstruction depending on local conditions. These included the owner-driven, subsidiary, participatory and contractor-driven approaches (Barenstein 2006).

Reconstruction authorities were established in the affected localities to facilitate and supervise reconstruction works. The beneficiaries were largely involved in communities where the owner-driven and participatory approaches were adopted. They participated in the design, estimation and construction while donor organizations provided ma- terials and financial resources. Beneficiary participation provided a sense of ownership and helped to reduce trauma resulting from disaster effects. High levels of satisfaction and construction quality were reportedly achieved (Barakat 2003; Barenstein 2006).

A good practice example from Sri Lanka was the establishment of construction guidelines and procedures for approvals and certification of reconstructed housing by the national Urban Development Authority (UDA) to ensure safe building construction (Ahmed, McEvoy 2010).

\subsection{Failures and poor practice examples}

The case study literature revealed several examples where factors led to reported failures of the different housing interventions. In Turkey, the non-involvement of the affected communities in both the design and selection of the location for housing reconstruction were criticized by the beneficiaries (Tas et al. 2007, 2010). The focus on quick disaster recovery reportedly led to hasty design resulting in important factors being overlooked such as the local climate and environment, socio-cultural factors and the beneficiaries' identity. Construction planning and production were also affected by inadequate selection of materials, ineffective use of labour, poor workmanship and supervision. All of these factors compromised the quality of the reconstructed houses (Tas et al. 2011).

From the contractors' side, there was criticism of the strict time constraints imposed on the projects. This, in some cases, reportedly led to excessive sub-contracting with severe consequences for the profitability of the main contractors (Balamir 2001).

In Sri Lanka, policy shifts and a lack of reliable data with respect to housing targets and reconstruction plans led to systemic confusion and delays in housing reconstruction. Coordination and communication issues arose and the demarcation of responsibilities was unclear (Uyangoda 2005; Grewal 2006).

Although construction guidelines had been established for housing reconstruction, they were not adequately followed by most reconstruction agencies and their enforcement by the national agency in charge was not uniform. A great deal of evidence of poor construction was observed. On some houses, "irremediable" defects were reported while many others required significant maintenance. However, beneficiaries tended to neglect 
this maintenance due to financial constraints and a lack of technical know-how.

Thus the buildings were left to become more vulnerable to hazard (Ahmed, McEvoy 2010).

Other factors that led to recorded failures of the Sri Lankan housing reconstruction program include the considerable pressure on implementing agencies for quick reconstruction, poor project management by implementation agencies leading to utilization of poor quality workmanship and substandard construction materials. In addition, competition among participating implementation agencies with a greater focus on the quantity rather than the quality of houses built and the non-inclusion of beneficiaries in the construction process (Barenstein 2006; Ahmed, McEvoy 2010).

In Gujarat, some of the materials and technology used in the housing reconstruction were considered unsuitable for the local weather and the cultural sensitivities of the community and this led to the rejection of some housing (Barenstein 2006).

Numerous home owners in Gujarat expressed displeasure with the contractor-led approach. This was largely due to a perception of poor building materials and low quality workmanship and it resulted in the rejection of housing. Some community members chose to repair and remain in their old homes rather than live in the poorly constructed new buildings (Barenstein 2006).

In Bam, failures were reported especially in buildings where new construction methods were employed. Structural joints failed where elements had not been properly installed. Semi-skilled labourers who were expected to gain some degree of knowledge did not acquire it due to inadequate supervision and mentoring and this affected their ability to carry out effective maintenance. Poor workmanship was also reported. This was considered to be due to poor supervision (Gharaati, Davidson 2008).

In Aceh, failures occurred due to inadequate management planning both at the strategic and operational levels. The time allowed to mobilise participating community members and to resolve land allocation issues delayed implementation start-up. The lack of resources - construction experts and skilled labour - alongside inadequate material procurement and logistics arrangements created setbacks for the project. Other issues including poor coordination and inadequate supervision also negatively impacted the speed and quality of housing delivery (ACARP 2007; Kennedy et al. 2008; Ophiyandri et al. 2010).

\subsection{Issues affecting the management of housing reconstruction initiatives}

Considerable challenges arise in large scale postdisaster reconstruction situations. These include access, logistical, health and safety issues, inadequate resources and more (Davidson et al. 2007; Ophiyandri et al. 2013). Such challenges are recurring and continue to affect the implementation of housing reconstruction programmes resulting in beneficiaries' dissatisfaction. This has often led to the modification or outright rejection of the housing provided. In some cases, the houses are even dismantled for their components (Shaw, Ahmed 2010; Ahmed 2011). For housing reconstruction programmes to be effective and successful, these issues need to be adequately managed. The primary issues emerging from the case study literature together with a brief explanation of each are summarized below.

\section{Logistics and supplies}

Reconstruction programmes are dependent on the delivery of supplies to the point of need. Whether this calls for the re-establishment of local supply chains or the bulk import of resources is context dependent but, in either case, the largescale but uncertain levels of demand call for a high degree of logistics expertise. Markets in the affected areas tend to be in disarray due to disrupted access, infrastructure and services. And even where local markets are still functioning, the scale of demand can cause local shortages and price rises (Gustavsson 2003; Kovacs, Spens 2007; Altay 2008; Lyons 2009; Chang et al. 2011).

\section{Human resource issues}

Large-scale reconstruction programmes are often beyond the capacity of local construction industries leading to a shortage of experts and skilled labour. This may be dealt with by up-skilling and training labour from the beneficiary communities, importing expertise and skilled labour from neighboring regions or from abroad. In either case, specific human resource-related challenges arise within the reconstruction programmes (Le Masurier et al. 2006; Kennedy et al. 2008; Petal et al. 2008; Zuo et al. 2008; Jayasuriya, McCawley 2008; Chang et al. 2011; Chang-Richards et al. 2013).

\section{Health and safety}

Construction operations are unacceptably dangerous at the best of times but the post-disaster environment is considerably more hazardous with debris, unsafe structures, damaged infrastructure, contaminated water, etc. Health and safety challenges therefore present a specific management issue for reconstruction operations (Sawacha et al. 1999; Attalla et al. 2004; Kennedy et al. 2008; Grosskopf 2010). 


\section{Risk management issues}

Beyond health and safety issues, the disrupted post-disaster environment also calls for enhanced risk management in other spheres. For example, the bonding issues between old and new materials which arose in the Bam housing reconstruction programme illustrate the risks associated with technological innovations (Gharaati, Davidson 2008).

\section{Financial management}

Financial arrangements for reconstruction programmes can be very complex with multiple funding sources (domestic and international NGOs, bi-lateral and multi-lateral donors) all with their own accounting requirements and allocation timeframes (Jayasuriya, McCawley 2008; Fengler et al. 2008). This can lead to conditions which compromise reconstruction implementation in terms of efficiency, quality, etc. (Freeman 2004; Steinberg 2007). The inflow of funds may also cause local price inflation (Jayasuriya, McCawley 2008; Lyons 2009).

\section{Monitoring and control}

Although detailed planning for reconstruction may be in place, the many difficulties constraining implementation including shortages of capable management and technical personnel can lead to delays and cost overruns. The monitoring and control function thus represents a particular challenge in reconstruction programmes (Assaf, Al-Hejji 2006; Kennedy et al. 2008; Ophiyandri et al. 2010).

Workmanship and quality management issues

Poor quality workmanship has been a common feature of many housing reconstruction projects (Gharaati 2007; Kennedy et al. 2008). This has been variously associated with a lack of skills and expertise, site conditions, poor quality materials but, primarily, with management failures (inadequate monitoring and supervision, communication problems, etc.) (Gharaati 2007; Fallahi 2007; Ophiyandri et al. 2010).

\section{Communication and coordination}

Achieving effective collaboration between the many entities working to deliver reconstruction programmes presents a considerable communication and coordination challenge (McEntire 1999; Altay 2008; Shaw, Ahmed 2010; Nakagawa, Shaw 2004; Patel, Hastak 2013).

\section{HOUSING RECONSTRUCTION DELIVERY APPROACHES}

The selection of an appropriate reconstruction delivery approach depends on numerous factors including resource availability, capacities and experience, speed, efficiency, technological and socioeconomic considerations (Barenstein 2006; Davidson et al. 2006; Hayles 2010; Chang et al. 2011). Several approaches are identified in the literature such as contractor-driven, technology-driven, participatory, community-based, and so on (Barakat 2003; Barenstein 2006; Twigg 2006). However, Barakat (2003) observed that there are no precisely defined approaches - practical approaches have to be tailored to the specific post-disaster context. In order to define a specific management strategy that is appropriate to a specific post-disaster context, the set of decisions to be taken in defining that management strategy must be considered in greater detail than simply the choice of leading stakeholder group (e.g. owner-led) or the focus of the intervention (e.g. technology-driven). For this reason it is necessary to identify the underlying 'elements' of management strategies which reflect each decision to be made in determining an appropriate management strategy.

In this paper, the discussion is limited to comparing the two extreme 'poles' of the general delivery approaches referred to in the literature the top-down, contractor-driven approach and the bottom-up, community-based approach - in order to indicate the wide range of delivery possibilities that exist between these and to make a first attempt at revealing some of the component management considerations or elements of management strategies which underlie these approaches.

\subsection{Contractor-driven approach}

Under the contractor-led extreme, housing reconstruction is contracted to professional construction firms that are often responsible for designing and building the houses. This approach is categorized into two types: in-situ where housing is reconstructed on the same site that was affected by the disaster; and ex-nihilo where the reconstruction takes place at a new site (Barakat 2003; Barenstein 2006).

Authors including Barenstein (2006) and Felix et al. (2013) observed that the contractor-led approach is faster and effective in urban settings. However, the principal drawbacks of this approach include inadequate consideration for affected communities' socio-cultural needs and the introduction of construction materials and technologies that may not be appropriate for the environment in which they are being used and this may lead to acceptability and maintainability issues (Barenstein 2006; Shaw, Ahmed 2010). 


\subsection{Community-driven approach}

Involvement of affected communities in housing reconstruction after disasters is critical to the success of the initiative (Lawther 2009). The community-led approach does not necessarily involve prospective owners reconstructing their houses themselves but does place the community at the centre of the reconstruction process with external support provided in the form of building materials, training, finance, technical services and supervision (Barenstein 2006).

Community-led approaches have become popular with donor agencies and, under the right conditions, they provide employment and livelihood benefits and they help to overcome psychological trauma. They can enable community empowerment and capacity development, cost effectiveness, better housing quality, early occupation of housing units and improve long-term maintenance prospects (Barakat 2003; Barenstein 2006; Fallahi 2007).

However, the use of the community-based approach is no panacea. Its success depends on other factors including stakeholder coordination, effective management processes and resource availability. Its appropriateness can also be limited by the technical complexity and scale of the housing reconstruction (Barakat 2003; Barenstein 2006; Lizarralde, Massyn 2008; Lawther 2009).

\section{OUTCOME GOALS}

Housing reconstruction programmes may have various objectives (Barakat 2003). The literature review above has already implied the existence of a generally applicable set of outcome goals by ascribing the notions of 'successes' and 'failures' to aspects of the case studies. Some examples of outcome goals identified from the literature are further elaborated below. However, it should be noted that there is considerable overlap between these goal descriptions and also that the list below is not exhaustive.

\section{Reestablishment of permanent community}

Provision of permanent housing addresses the issues of shelter, privacy and dignity. It reduces the traumatic effect of the catastrophic event, restores confidence and trust and provides safety and security to the affected communities. This in turn allows the community members to reestablish their livelihoods. (Kennedy et al. 2008; Niazi, Anand 2010).

Acceptability of reconstructed housing

Acceptability relates to the functionality, good quality and habitability of reconstructed housing from the occupants' perspective (Da Silva 2010; Shaw, Ahmed 2010). There is a direct correlation between product quality, beneficiary satisfaction and acceptability (UN-HABITAT 2006).

\section{Socio-economic recovery}

The need for socio-economic revival of affected communities has been noted as an outcome goal by several authors (Johnson et al. 2006; Lyons 2009; Mannakkara, Wilkinson 2013, 2014). This may be enabled through psycho-social well-being (Mooney et al. 2011), skills acquisition and training programmes, and through employment, particularly in the reconstruction and future maintenance of the buildings (Steinberg 2007; Lyons 2009). Postdisaster reconstruction interventions may also be used as opportunities to solve long-standing housing supply issues (Tas et al. 2010).

Quick reconstruction and recovery

Affected communities and investors need housing reconstruction projects to be rapidly realized to foster recovery. Yet numerous studies (including Steinberg 2007; Iwai, Tabuchi 2013) have shown that most reconstruction projects are completed behind schedule.

\section{Housing quality and sustainability}

Donors and other stakeholders expect the recreation of a high-quality environment so that quality housing is one of the key objectives for any permanent housing reconstruction intervention (Da Silva 2010). Authors including Pearce (2003) and Davidson et al. (2007) have observed that the participation of the community in the reconstruction process helps to ensure the sustainability of the constructed housing.

\section{Risk reduction}

A general consensus exists in the literature that priority should be given to sustainable hazard mitigation through the incorporation of disaster risk reduction measures into housing reconstruction (El-Masri, Tipple 2002; Wamsler 2004; Bosher et al. 2007). According to Clinton (2006), reconstruction and recovery programmes must leave communities safer by putting in place risk reduction strategies in all phases of reconstruction. Similarly, the 'build back better' concept relates to integrating both structural and non-structural disaster risk reduction measures into the planning, design and implementation of reconstruction programmes (Lyons 2009; Kennedy et al. 2008; Mannakkara, Wilkinson 2013, 2014).

\section{PROPOSING A FRAMEWORK FOR SELECTING MANAGEMENT STRATEGIES}

This literature review has confirmed the need for the improved management of housing reconstruc- 
tion initiatives and has provided some insights into the housing reconstruction problem as follows:

\section{Contextual dependence}

In section 3 , a number of characteristics of the post-disaster context were identified but the degree to which each of these factors differs from their normal status depends upon the nature of the particular situation. The implication being that, for each post-disaster context, a unique housing reconstruction problem will arise and this calls for a management strategy specifically tailored to suit it.

Complex interrelationships between contextual characteristics, management strategies and outcomes

A wealth of experience exists with regard to previous housing reconstruction initiatives. The literature review showed that both positive and negative aspects of historical reconstruction programmes are evidenced. However, one striking feature of this evidence is the complexity of the interplay between contextual characteristics, management strategies and outcomes. For example, elements of certain strategies (e.g. the contractordriven approach) were reported to be effective in addressing particular outcomes (the need for speed) while, at the same time, they were criticized for worsening others (quality).

\section{Specific management issues}

Relating to both the above points, a number of management issues are seen to have recurred in historical housing reconstruction programmes (see section 4.3). These can be thought of as the contextual characteristics emerging as specific challenges to be managed. The appearance and recurrence of a defined set of these issues in past initiatives suggests that they could provide a basis for a generic means to define context-specific management problems.

\section{Elements of management strategies}

The two extreme forms of delivery approach considered in section 5 (top-down / contractordriven and bottom-up / community-based) serve to illustrate that a range of specific management strategy elements can be identified which have varying appropriateness and utility in relation to the context (and consequently emerging management issues) and which will increase or decrease the likelihood of achieving particular outcome goals. From the literature reviewed in section 5, it follows that these management strategy elements would include but not be limited to decisions regarding the roles of the various stakeholders, the use of contractors, the siting of the new housing, materials and technological choices, financing and supervisory arrangements.

\section{Outcome goals}

A number of generally applicable outcome goals were identified (section 6). While these outcome goals exhibit considerable overlap and may be incomplete, they do serve to demonstrate the existence of a generally applicable set of outcome goals and this suffices for our purpose of proposing a conceptual framework to relate the post-disaster context (and the management issues which emerge from that) to management strategies and to desired outcomes.

\subsection{An initial conceptual framework}

The conceptual framework proposed in Figure 1 illustrates the suggested relationship between contextual characteristics elaborated into specific management issues, elements of management strategies to deal with these issues and the various

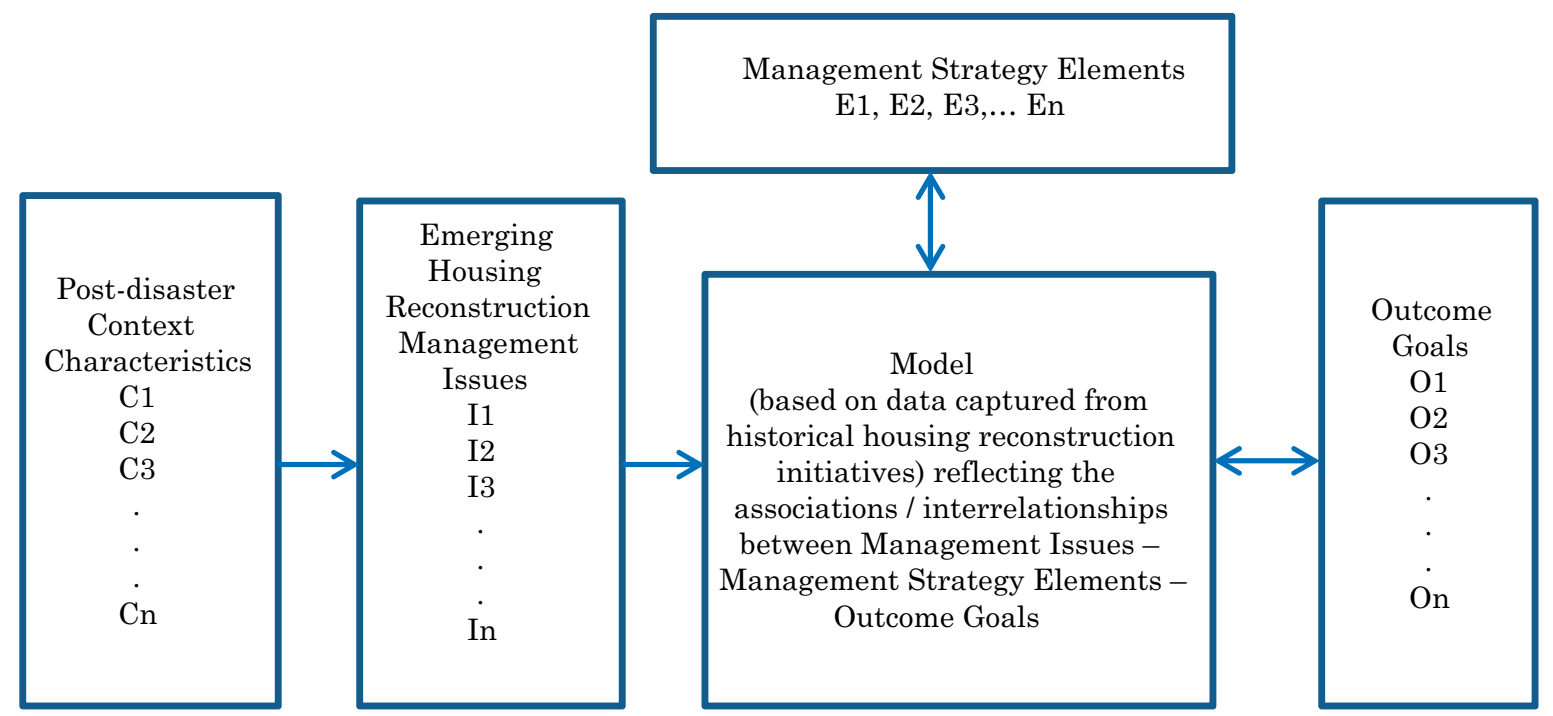

Fig. 1. Conceptual framework for effective housing reconstruction management strategies 
outcome goals which are desired to be achieved in implementing these strategies.

In the first instance, this framework provides a structure which enables the systematic collection of field data from current and historical housing reconstruction programmes (in terms of contextual factors, desired outcome goals and elements of the management strategies which have been adopted).

\subsection{Further research to develop the framework}

Once adequate field data have been gathered, it is expected that generic lists of the variables: significant characteristics $(\mathrm{C} 1, \mathrm{C} 2, \mathrm{C} 3, \ldots, \mathrm{Cn})$, management issues (I1, I2, I3, .., In), management strategy elements $(\mathrm{E} 1, \mathrm{E} 2, \mathrm{E} 3, \ldots, \mathrm{En})$ and outcome goals $(\mathrm{O} 1, \mathrm{O} 2, \mathrm{O} 3, \ldots, \mathrm{On})$, will be identified and that appropriate value scales can be derived for each of them so that evidence from any historical housing reconstruction intervention may be coded and captured in a database. This database can then be used to identify the relationships between these variables. Our proposition is that such a model could enable better understanding of the links between context, management strategies and outcomes so as to enable the selection of management strategy elements for desired outcome goals. It may also facilitate the anticipation of likely outcomes when elements of existing management strategies are input. (This dual functionality is indicated by the double-headed arrows between the Model and Management Strategy Elements and the Model and Outcome Goals in Figure 1). This would enhance our understanding of the management of housing reconstruction programmes and provide a much-needed decision support tool.

\section{CONCLUSIONS}

Post-disaster housing reconstruction represents a significant portion of global property investment yet the management of reconstruction programmes has often proved to be ineffective. While the postdisaster context admittedly makes the management challenge considerably greater than it is for housing construction under 'normal' property development conditions, it also offers exceptional opportunities to invest in and develop a more resilient built environment. Thus there is an urgent need to improve the management of reconstruction programmes.

To this end, a literature search was undertaken. Typical post-disaster contextual characteristics were identified and a list of common reconstruction management issues arising as a consequence of these was derived. Similarly, primarily from an analysis of historical reconstruction successes and failures, the existence of commonly desired outcomes was demonstrated and an initial list of outcome goals for reconstruction programmes was derived.

Management strategies are needed to address the management issues and achieve these outcome goals. The existing literature was found to offer only general descriptions of overall management approaches (e.g. contractor-driven, communitybased, etc.) but these are too broad to be directly useful. However, they did serve to indicate some of the elements which must be considered in determining a detailed management strategy.

These findings were then synthesized into a conceptual framework outlining the overall relationships between context, management issues, management strategy elements and outcome goals. This conceptual framework provides a basis for data collection.

The next step for this research will be to collect data from current and historical reconstruction initiatives so that the detailed relationships between these variables can be more fully understood. It is then intended to apply the acquired knowledge to develop decision-support tools for the management of housing reconstruction programmes.

\section{ACKNOWLEDGEMENTS}

This research was supported by the Collaborative Action towards Disaster Resilience Education (CADRE) project and the Academic Network for Disaster Resilience to Optimise Educational Development (ANDROID) academic network both funded with support from the European Commission. The findings and opinions reported in this paper reflect the views only of the authors, and the Commission cannot be held responsible for any use which may be made of the information contained in it.

\section{REFERENCES}

ACARP. 2007. The Acehnese Gampong three years on: assessing local capacity and reconstruction assistance in post-tsunami Aceh, Report of the Aceh Community Assistance Research Project (ACARP).

Agbola, S. B. 1998. The housing of Nigerians - a review of policy development and implementation. Research Report No. 14. Ibadan, Nigeria: Development Policy Centre. 
Ahmed, I. 2011. An overview of post-disaster permanent housing reconstruction in developing countries, International Journal of Disaster Resilience in the Built Environment 2(2): 148-164.

http://dx.doi.org/10.1108/17595901111149141

Ahmed, I.; McEvoy, D. 2010. Post-disaster housing reconstruction: post-occupancy case studies from Sri Lanka, in Proceedings of the $44^{\text {th }}$ Annual Conference of the Architectural Science Association, ANZAScA 2010, 24-26 November 2010, Unitec Institute of Technology, Auckland, New Zealand.

Altay, N. 2008. Issues in disaster relief logistics, in Gad-el-Hak, M. (Ed.). Large-scale disasters: prediction, control, and mitigation, Cambridge: Cambridge University Press, 120-146. http://dx.doi.org/10.1017/CBO9780511535963.007

Aluko, O. 2012. Effects of Land Use Act on sustainable housing provision in Nigeria: the Lagos state experience, Journal of Sustainable Development 5(1): 114122. http://dx.doi.org/10.5539/jsd.v5n1p114

Assaf, S.; Al-Hejji, S. 2006. Causes of delay in large construction projects, International Journal of Project Management 24(4): 349-357.

http://dx.doi.org/10.1016/j.ijproman.2005.11.010

Attalla, M.; Hegazy, T.; Elbeltagi, E. 2004. In-house delivery of multiple-small reconstruction projects, Journal of Management in Engineering 20(1): 25-31. http:// dx.doi.org/10.1061/(ASCE)0742-597X(2004)20:1(25)

Balamir, M. 2001. Problems in housing earthquake survivors, planning, in UCTEA Chamber of Urban Planners Publication 4, 5.

Barakat, S. 2003. Housing reconstruction after conflict and disaster, Network Paper 43, Commissioned and published by the Humanitarian Practice Network at Overseas Development Institute, London.

Barenstein, J. D. 2006. Housing reconstruction in postearthquake Gujarat: a comparative analysis, Network Paper 54, Commissioned and published by the Humanitarian Practice Network at Overseas Development Institute, London.

Bilau, A. A.; Witt, E.; Lill, I. 2015. A framework for managing post-disaster housing reconstruction, Procedia Economics and Finance 21: 313-320. http://dx.doi. org/10.1016/S2212-5671(15)00182-3

Bosher, L. S.; Dainty, A. R. J.; Carrillo, P. M.; Glass, J.; Price, A. F. 2007. Integrating disaster risk management into construction: a UK perspective, Building Research \& Information 35(2): 163-177. http://dx.doi. org/10.1080/09613210600979848

Bourne, L. S. 1981. The geography of housing. London: Edward Arnold.

CERA. 2012. Economic recovery programme for Greater Christchurch: a foundation for economic recovery and growth in greater Christchurch. Christchurch: Canterbury Earthquake Recovery Authority (CERA).

Chang, Y.; Wilkinson, S.; Brunsdon, D.; Seville, E.; Potangaroa, R. 2011. An integrated approach: managing resources for post-disaster reconstruction, Disasters 35: 739-765. http://dx.doi.org/10.1111/j.1467-7717.2011.01240.x

Chang, Y.; Wilkinson, S.; Seville, E.; Potangaroa, R. 2010. Resourcing for a resilient post-disaster recon- struction environment, International Journal of Disaster Resilience in the Built Environment 1(1): 65-83. http://dx.doi.org/10.1108/17595901011026481

Chang-Richards, Y.; Wilkinson, S.; Potangaroa, R.; Seville, E. 2013. Resource challenges for housing reconstruction: a longitudinal study of the Australian bushfires, Disaster Prevention and Management: An International Journal 22(2), 172-181. http://dx.doi.org/10.1108/09653561311325316

Clinton, W. J. 2006. Lessons learned from tsunami recovery: key propositions for building back better, United Nations Secretary-General's Special Envoy for Tsunami Recovery, United Nations, New York.

Da Silva, J. 2010. Lessons from Aceh: key considerations in post-disaster reconstruction. Warwickshire: Ove Arup Partners Ltd. and Disasters Emergency Committee. http://dx.doi.org/10.3362/9781780440606

Davidson, C. H.; Johnson, C.; Lizarralde, G.; Dikmen, N.; Sliwinski, A. 2007. Truths and myths about community participation in post-disaster housing projects, Habitat International 31: 100-115.

http://dx.doi.org/10.1016/j.habitatint.2006.08.003

DNS and PASA. 2006. Tackling the tides and tremors: South Asia disaster report 2005. Duryog Nivaran Secretariat (DNS) and Practical Action South Asia (PASA), London: I.T.D.G. Publications.

EEA. 2006. Multilingual environment glossary [online]. European Environment Agency (EEA). Available at: http://glossary.eea.europa.eu/EEAGlossary [accessed 26 December 2014]

El-Masri, S.; Tipple, G. 2002. Natural disaster, mitigation and sustainability: the case of developing countries, International Planning Studies 7(2): 157-175. http://dx.doi.org/10.1080/13563470220132236

Fallahi, A. 2007. Lessons learned from the housing reconstruction following the Bam earthquake in Iran, The Australian Journal of Emergency Management 22(1): 26-35.

Felix, D.; Branco, J. M.; Feio, A. 2013. Temporary housing after disasters: a state of the art survey, Habitat International 40: 136-141. http://dx.doi.org/10.1016/j.habitatint.2013.03.006

Fengler, W.; Ihsan, A.; Kaiser, K. 2008. Managing postdisaster reconstruction finance: international experience in public financial management. World Bank Publications. http://dx.doi.org/10.1596/1813-9450-4475

Freeman, P. K. 2004. Allocation of post-disaster reconstruction financing to housing, Building Research and Information 32(5): 427-437. http://dx.doi.org/10.1080/0961321042000221016

Ghafory-Ashtiany, M.; Hosseini, M. 2008. Post-Bam earthquake: recovery and reconstruction, Natural Hazards 44(2): 229-241. http://dx.doi.org/10.1007/s11069-007-9108-3

Gharaati, M. 2007. An overview of the reconstruction programme after the earthquake in Bam, Iran, in: Alexander, D.; Davidson, C. H.; Fox, A.; Johnson, C.; Lizarralde, G. (Eds.). Post-disaster reconstruction meeting stakeholder interests, Florence (Italy), the University Press, 253-262.

Gharaati, M., Davidson, C. 2008. Who knows best? An overview of reconstruction after the earthquake in Bam, Iran, in: Proceedings of the $4^{\text {th }}$ International 
i-Rec conference 2008 Building resilience: achieving effective post-disaster reconstruction, 30 April-2 May 2008, Christchurch, New Zealand.

Godschalk, D. R. 2003. Urban hazard mitigation: creating resilient cities, Natural Hazards Review 4(3): 136-143.

Grewal, M. K. 2006. Approaches to equity in post-tsunami assistance - Sri Lanka: a case study [online]. Department of International Development, London and Office of the UN Secretary General's Special Envoy for Tsunami Recovery. Available at: file:///C:/ Users/Audrius/Downloads/approachestoequity.pdf [accessed 27 January 2015]

Grosskopf, K. R. 2010. Post-disaster recovery and reconstruction safety training, International Journal of Disaster Resilience in the Built Environment 1(3): 322333. http://dx.doi.org/10.1108/17595901011080904

Guha-Sapir, D.; Vos, F.; Below, R.; Ponserre, S. 2011. Annual disaster statistical review 2010: the numbers and trends. Brussels: CRED.

Gustavsson, L. 2003. Humanitarian logistics: context and challenges, Forced Migration Review 18: 6-8.

Haigh, R.; Amaratunga, D. 2010. An integrative review of the built environment discipline's role in the development of society's resilience to disasters, International Journal of Disaster Resilience in the Built Environment 1(1): 11-24.

http://dx.doi.org/10.1108/17595901011026454

Hayles, C. S. 2010. An examination of decision making in post disaster housing reconstruction, International Journal of Disaster Resilience in the Built Environment 1(1): 103-122.

http://dx.doi.org/10.1108/17595901011026508

Ismail, D.; Majid, T. A.; Roosli, R.; Samah, N. 2014. Project management success for post-disaster reconstruction projects: international NGOs perspective, Procedia Economics and Finance 18: 120-127. http://dx.doi.org/10.1016/S2212-5671(14)00921-6

Iwai, T.; Tabuchi, S. 2013. Survey: housing projects delayed for more than 10,000 evacuees. The Asahi Shimbun.

Jayasuriya, S.; McCawley, P. 2008. Reconstruction after a major disaster: lessons from the post-tsunami experience in Indonesia, Sri Lanka, and Thailand, Asian Development Bank Institute Working Paper No. 125.

Johnson, C. 2007. Strategic planning for post-disaster temporary housing, Disasters 31(4): 435-458. http:// dx.doi.org/10.1111/j.1467-7717.2007.01018.x

Johnson, C.; Lizarralde, G.; Davidson, C. H. 2006. A systems view of temporary housing projects in post-disaster reconstruction, Construction Management and Economics 24: 367-378. http://dx.doi. org/10.1080/01446190600567977

Kennedy, J.; Ashmore, J.; Babister, E.; Kelman, I. 2008. The meaning of 'build back better': evidence from post-tsunami Aceh and Sri Lanka, Journal of Contingencies and Crisis Management 16(1): 24-36. http://dx.doi.org/10.1111/j.1468-5973.2008.00529.x

Kovacs, G.; Spens, K. M. 2007. Humanitarian logistics in disaster relief operations, Journal of Physical Distribution \& Logistics Management 37(2): 99-114. http://dx.doi.org/10.1108/09600030710734820
Lawther, P. M. 2009. Community involvement in post disaster re-construction - case study of the British Red Cross Maldives recovery programme, International Journal of Strategic Property Management 13: 153-169. http://dx.doi.org/10.3846/1648715X.2009.13.153-169

Le Masurier, J.; Wilkinson, S.; Shestakova, Y. 2006. An analysis of the alliancing procurement method for reconstruction, in Proceedings of the $8^{\text {th }}$ U.S. National Conference on Earthquake Engineering, 18-22 April 2006, San Francisco, California, USA. Paper No. 290.

Lester, R. 2003. The World Bank perspective on national catastrophe risk management, in The World Bank Conference on 'Financing the Risks of Natural Disasters: a New Perspective on Country Risk Management', 2-3 June 2003, Washington, DC.

Lindell, M. K.; Prater, C. S. 2003. Household adoption of seismic hazard adjustments: a comparison of residents in two states, International Journal of Mass Emergencies and Disasters 18: 317-338.

Liu, L.; Liu, J. 2014. Experience of the post-disaster housing rehabilitation and reconstruction in Wudu District, Longnan City, in Proceedings of the $17^{\text {th }}$ International Symposium on Advancement of Construction Management and Real Estate, 17-18 November 2012, Shenzhen, China. Dordrecht: Springer, 709714. http://dx.doi.org/10.1007/978-3-642-35548-6_73

Lizarralde, G.; Massyn, M. 2008. Unexpected negative outcome of community participation in lowcost housing project in South-Africa, Habitat International 32(1): 1-14. http://dx.doi.org/10.1016/j.habitatint.2007.06.003

Low, S. M.; Chambers, E. 1989. Housing, culture, and design: a comparative perspective. University of Pennsylvania Press.

Lyons, M. 2009. Building back better: the large-scale impact of small-scale approached to reconstruction, World Development 37(2): 385-398. http://dx.doi.org/10.1016/j.worlddev.2008.01.006

Mannakkara, S.; Wilkinson, S. 2013. Build back better principles for post-disaster structural improvements, Structural Survey 31(4): 314-327. http://dx.doi.org/10.1108/SS-12-2012-0044

Mannakkara, S.; Wilkinson, S. 2014. Re-conceptualising "building back better" to improve post-disaster recovery, International Journal of Managing Projects in Business 7(3): 327-341. http://dx.doi.org/10.1108/IJMPB-10-2013-0054

McEntire, D. A. 1999. Issues in disaster relief: progress, perpetual problems and prospective solutions, Disaster Prevention and Management: An International Journal 8(5): 351-361. http://dx.doi.org/10.1108/09653569910298279

Mooney, M. F.; Paton, D.; de Terte, I.; Johal, S.; Karanci, A. N.; Gardner, D.; Collins, S.; Glavovic, B.; Huggins, T. J.; Johnston, L.; Chambers, R.; Johnson, D. 2011. Psychosocial recovery from disasters: a framework informed by evidence, New Zealand Journal of Psychology 40(4): 26-38.

Munich Re. 2013. Topics Geo [online]. Available at: http:// www.munichre.com/site/corporate/get/documents_ E1060573842/mr/assetpool.shared/Documents/0_Corporate\%20Website/_Publications/302-08121_en.pdf [accessed 10 January 2015] 
Nakagawa, Y.; Shaw, R. 2004. Social capital: a missing link to disaster recovery, International Journal of Mass Emergencies and Disasters 22(1): 5-34.

Neilson, M. 2004. Scottish Housing Quality Standard (SHQS). Scottish Executive Development Department.

Niazi, Z.; Anand, C. 2010. Post-tsunami reconstruction in South India: lessons for habitat development, in Lizarralde, G.; Jigyasu, R.; Vasavada, R.; Havelka, S.; Duyne Barenstein, J. (Eds.). Proceedings of the i-Rec 2010 Conference on Participatory Design and Appropriate Technology for Post-Disaster Reconstruction, 15-20 July 2010, Ahmedabad, India. Montreal: Groupe de recherche IF, GRIF, Université de Montréal, 110-122.

Nuuter, T.; Lill, I.; Tupenaite, L. 2014. Ranking of housing market sustainability in selected European countries, WSEAS Transactions on Business and Economics 11: 778-786.

Ophiyandri, T.; Amaratunga, D.; Pathirage, C.; Keraminiyage, K. 2013. Critical success factors for community-based post-disaster housing reconstruction projects in the pre-construction stage in Indonesia, International Journal of Disaster Resilience in the Built Environment 4(2): 236-249. http://dx.doi.org/10.1108/IJDRBE-03-2013-0005

Ophiyandri, T.; Amaratunga, R. D. G.; Pathirage, C. P. 2010. Community based post disaster housing reconstruction: Indonesian perspective, in Proceedings of the CIB 2010 World Congress, 10-13 May 2010, University of Salford.

Otero, R. C.; Marti, R. Z. 1995. The impacts of natural disasters on developing economies: implications for International development and disaster community, in Disaster prevention for sustainable development: economic and policy issues. Washington DC, World Bank, 11-40.

OXFAM. 2006. Oxfam International Tsunami Fund International, Second Year Report December 2006.

Patel, S.; Hastak, M. 2013. A framework to construct post-disaster housing, International Journal of Disaster Resilience in the Built Environment 4(1): 95114. http://dx.doi.org/10.1108/17595901311299026

Pearce, L. 2003. Disaster management community planning, and public participation: how to achieve sustainable hazard mitigation, Natural Hazards 28(2-3): 211-228. http://dx.doi.org/10.1023/A:1022917721797

Petal, M.; Green, R.; Kelman, I.; Shaw, R.; Dixit, A. 2008. Community-based construction for disaster risk reduction, in Bosher, L. (Ed.). Hazards and the built environment, London: Taylor and Francis.

Rapoport, A. 2001. Theory, culture and housing, Housing, Theory and Society 17: 145-165. http://dx.doi.org/10.1080/140360900300108573

Rotimi, J. O.; Wilkinson, S.; Zuo, K.; Myburgh, D. 2009. Legislation for effective post-disaster reconstruction, International Journal of Strategic Property Management 13(2): 143-152. http://dx.doi.org/10.3846/1648715X.2009.13.143-152

Sadiqi, Z.; Coffey, V.; Trigunarsyah, B. 2011. Post-disaster housing reconstruction: challenges for community participation, in Proceedings of the international conference on Building Resilience: interdisciplinary approaches to disaster risk reduction, and the development of sustainable communities. Heritance Kandalama, Sri Lanka.

Sawacha, E.; Naoum, S.; Fong, D. 1999. Factors affecting safety performance on construction sites, International Journal of Project Management 17(5): 309315. http://dx.doi.org/10.1016/S0263-7863(98)00042-8

Seneviratne, K.; Baldry, D.; Pathirage, C. 2010. Disaster knowledge factors in managing disasters successfully, International Journal of Strategic Property Management 14: 376-390.

http://dx.doi.org/10.3846/ijspm.2010.28

Shaw, J.; Ahmed, I. 2010. Design and delivery of postdisaster housing resettlement programs: case studies from Sri Lanka and India. Report 6. Monash Asia Institute, Monash University.

Steinberg, F. 2007. Housing reconstruction and rehabilitation in Aceh and Nias, Indonesia - rebuilding lives, Habitat International 31(1): 150-166. http://dx.doi.org/10.1016/j.habitatint.2006.11.002

Sullivan, M. 2003. Communities and their experience of emergencies, Australian Journal of Emergency Management 18(1): 19-26.

Tas, M.; Tas, N.; Cosgun, N. 2010. Study on permanent housing production after 1999 earthquake in Kocaeli (Turkey), Disaster Prevention and Management 19: 6-19. http://dx.doi.org/10.1108/09653561011022108

Tas, N.; Cosgun, N.; Tas, M. 2007. A qualitative evaluation of the after earthquake permanent housings in Turkey in terms of user satisfaction - Kocaeli, permanent housing model, Building and Environment 42(9): 3418-3431. http://dx.doi.org/10.1016/j.buildenv.2006.09.002

Tas, N.; Tas, M.; Cosgun, N. 2011. Permanent housing production process after 17 August 1999 Marmara Earthquake in Turkey, International Journal of Strategic Property Management 15: 312-328. http://dx.doi.org/10.3846/1648715X.2011.617863

Twigg, J. 2006. Technology, post disaster housing reconstruction and livelihood security, Working Paper No. 15. London: Benfield Hazard Research Centre.

UN-HABITAT. 2006. Aceh Nias housing \& settlements reconstruction newsletter, No. 6, 18 May 2006.

UN-ISDR. 2007. Words into action: a guide to implementing the Hyogo Framework. United Nations, International Strategy for Disaster Reduction.

Uyangoda, J. 2005. Post-tsunami recovery in Sri Lanka, Polity 2(3): 4-7.

Wamsler, C. 2004. Managing urban risk: perceptions of housing and planning as a tool for reducing disaster risk, Global Built Environment Review 4(2): 11-28.

Yi, H.; Yang, J. 2014. Research trends of post disaster reconstruction: the past and the future, Habitat International 42: 21-29. http://dx.doi.org/10.1016/j.habitatint.2013.10.005

Zuo, K.; Wilkinson, S.; Potangaroa, R. 2008. Supply chain and material procurement for post disaster construction: the Boxing Day Tsunami reconstruction experience in Aceh, Indonesia, in Haigh, R.; Amaratunga, D. (Eds.). CIB W89 International Conference on Building Education and Research BEAR 2008, 11-15 February 2008, Heritance Kandalama, Sri Lanka, 1116-1133. 